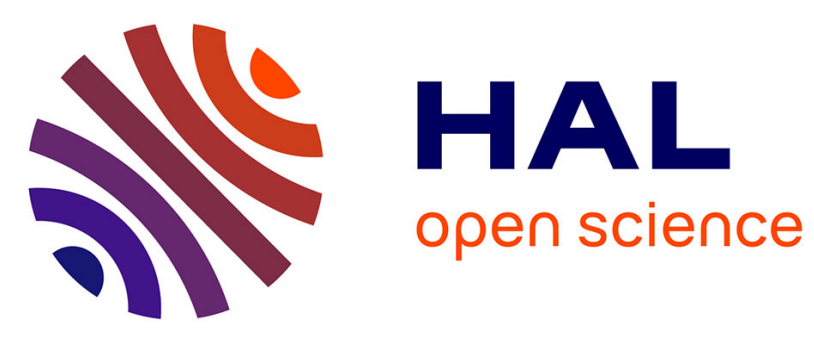

\title{
Thelytoky in the honey bee
}

Frances Goudie, Benjamin Oldroyd

\section{To cite this version:}

Frances Goudie, Benjamin Oldroyd. Thelytoky in the honey bee. Apidologie, 2014, 45 (3), pp.306-326. 10.1007/s13592-013-0261-2 . hal-01234740

\section{HAL Id: hal-01234740 https://hal.science/hal-01234740}

Submitted on 27 Nov 2015

HAL is a multi-disciplinary open access archive for the deposit and dissemination of scientific research documents, whether they are published or not. The documents may come from teaching and research institutions in France or abroad, or from public or private research centers.
L'archive ouverte pluridisciplinaire HAL, est destinée au dépôt et à la diffusion de documents scientifiques de niveau recherche, publiés ou non, émanant des établissements d'enseignement et de recherche français ou étrangers, des laboratoires publics ou privés. 


\title{
Thelytoky in the honey bee
}

\author{
Frances Goudie, Benjamin P. Oldroyd
}

Behavior and Genetics of Social Insects Laboratory A12, University of Sydney, Sydney, NSW 2006, Australia

Received 24 July 2013 - Revised 11 November 2013 - Accepted 2 December 2013

\begin{abstract}
Thelytoky, the asexual production of females, is rare in honey bees. However, it is ubiquitous in workers of the Cape honey bee Apis mellifera capensis. Thelytoky allows some workers to be reincarnated into the queen phenotype, and thereby selects for reproductive competition among workers. Thelytoky also acts as an exaptation for the emergence of reproductive parasites, the most extreme example of which is an entirely clonal 'cancerous' lineage of workers (the Clone) that lethally parasitises colonies of another subspecies Apis mellifera scutellata. The Clone is an enigma because thelytoky results in the accumulation of homozygosity at any loci that are free to recombine, yet the Clone retains considerable heterozygosity. The Clone pays a cost for its thelytoky: the selective removal of homozygous offspring at each generation. We propose that workers, queens and Clones have differing abilities to endure the costs and benefits of sex and asexuality, accounting for the heterogeneous distribution of reproductive strategies across the A. mellifera capensis population. We further suggest that multiple factors must fall into place for thelytoky to emerge as an effective reproductive strategy in a honey bee population, and that geographic isolation resulting in genetic drift and founder effects may have enabled thelytoky to emerge in A. mellifera capensis. Finally, we consider the honey bee in the broader context of haplodiploid Hymenoptera, and argue that constraints on the evolution of sex in non-haplodiploid taxa may make sexual reproduction an evolutionary 'one-way street'.
\end{abstract}

\section{Apis mellifera / Apis mellifera capensis / asexual / thelytoky / reproductive parasitism}

\section{INTRODUCTION}

In the typical image of a honey bee (Apis mellifera) colony, there is a queen reigning over her worker force of daughters with an iron... wing? The queen, and only the queen, lays eggs. If she chooses to fertilise an egg with stored sperm, it develops as a diploid daughter, a future queen or worker. Alternatively, if the queen lays an unfertilised egg, it develops into a haploid male, a drone that will eventually fly out and attempt to mate with virgin queens of other colonies.

This image might come close to approximating a particularly well-behaved colony of the European honey bee. However, in reality, like the human suburbs of the 1950s, even the best-behaved honey bee colonies can have nefarious goings on beneath the surface. Here, we review one of the most fascinating ways in which reality differs from outward appearance: the asexual production of diploid females via thelytokous parthenogenesis. We discuss the physiological, evolutionary and social consequences of thelytoky in the subspecies in which is best characterised, the Cape honey bee Apis mellifera capensis (hereafter, Capensis). We further discuss the possibility of thelytoky in other honey bee species and subspecies, and explore how thelytoky may have evolved in honey bees.

\subsection{Thelytoky}

Corresponding author: F. Goudie, frances.goudie@sydney.edu.au Manuscript editor: Stan Schneider are normally produced sexually, from fertilised
Honey bees are haplodiploid. Diploid females 
eggs, while haploid males develop from unfertilized eggs via arrhenotokous parthenogenesis. Both queens and workers are capable of laying unfertilised, male-destined eggs, although in most circumstances workers rarely utilise this ability (Visscher 1989; Winston 1991; but see Barron et al. 2001). Thelytoky is an alternative developmental pathway for the unfertilised egg, which results in the production of a diploid female offspring.

Thelytoky, the asexual production of females, is rare among animal taxa, where sexual reproduction predominates (White 1984; Suomalainen et al. 1987). Examples of notable thelytokous animals include the anciently asexual bdelloid rotifer, which has gone without sex for millions of years (Mark Welch et al. 2004; Gladyshev and Meselson 2008) and the Amazon molly (Poecilia formosa), in which females must mate with males of another species before they can reproduce thelytokously. This odd behaviour causes local extinctions as molly females 'steal all the men' (Tiedemann et al. 2005; Heubel et al. 2009).

Thelytoky has evolved at least 255 times in populations of normally arrhenotokous haplodiploids (Normark 2003; Engelstadter 2008). Many transitions from arrhenotoky to thelytoky are driven by maternally transmitted endobacteria, such as Wolbachia, Rickettsia and Cardinium (Zchori-Fein et al. 2001; Huigens and Stouthamer 2003; Hagimori et al. 2006; Engelstadter 2008). One mechanism by which these bacteria drive their own propagation is by inducing female-producing parthenogensis to reduce or eliminate the production of males (a genetic dead end for the bacteria) by their host. However, there are a rapidly increasing number of examples of genetically determined thelytoky being identified in haplodiploids. In particular, the 'molecular natural history' movement (Keller 2007) is revealing a fascinating array of novel reproductive systems that are based on genetically determined thelytoky. While the ants have thus far yielded the greatest diversity of unusual reproduction systems based on thelytoky (e.g. Pearcy et al. 2004; Ravary and Jaisson 2004; Fournier et al. 2005; Gruber et al. 2010), the bees, and particularly the honey bees, are beginning to show that they can be equally weird (Sumner and Keller 2008).

\section{APIS MELLIFERA CAPENSIS}

\subsection{Thelytoky in Capensis}

Thelytoky in bees was first identified in Capensis (Onions 1912). In this South African subspecies of honey bee, thelytoky is almost ubiquitous in workers (Verma and Ruttner 1983). When Capensis workers lay unfertilised eggs, the eggs usually develop into diploid female offspring via automictic thelytoky with central fusion (Verma and Ruttner 1983; Figure 1). In automictic thelytoky, the reductional division of Meiosis II occurs as normal, resulting in four haploid nuclei. Diploidy is then restored by one of several mechanisms, each with a different genetic outcome (Pearcy et al. 2006). In Capensis, diploidy is restored by central fusion; the fusion of two nonhomologous pronuclei as if one of the nuclei acted as a sperm. In the absence of meiotic recombination between a locus and the centromere, central fusion results in clonal reproduction so that the genotype of the daughter is identical to the genotype of the mother. However, when recombination occurs, heterozygosity can be lost, so that the daughter will be homozygous for one of her mother's alleles (Suomalainen et al. 1987).

If a Capensis worker produces a daughter queen via thelytoky, she is genetically reincarnated in the form of a queen with no frog kissing required. This is no doubt why Capensis workers target their egg laying around existing queen cells, in places where queen cells are likely to be built and during periods of queen rearing (Figure 2). Around 40-60\% of queens produced during swarming events are the daughters of workers (Jordan et al. 2008; Allsopp et al. 2010). Thelytokously-produced Capensis queens go on to mate and reproduce sexually (Beekman et al. 2011). Capensis workers also utilise thelytoky to raise a replacement queen whenever they are queenless and broodless (Holmes et al. 2010). 


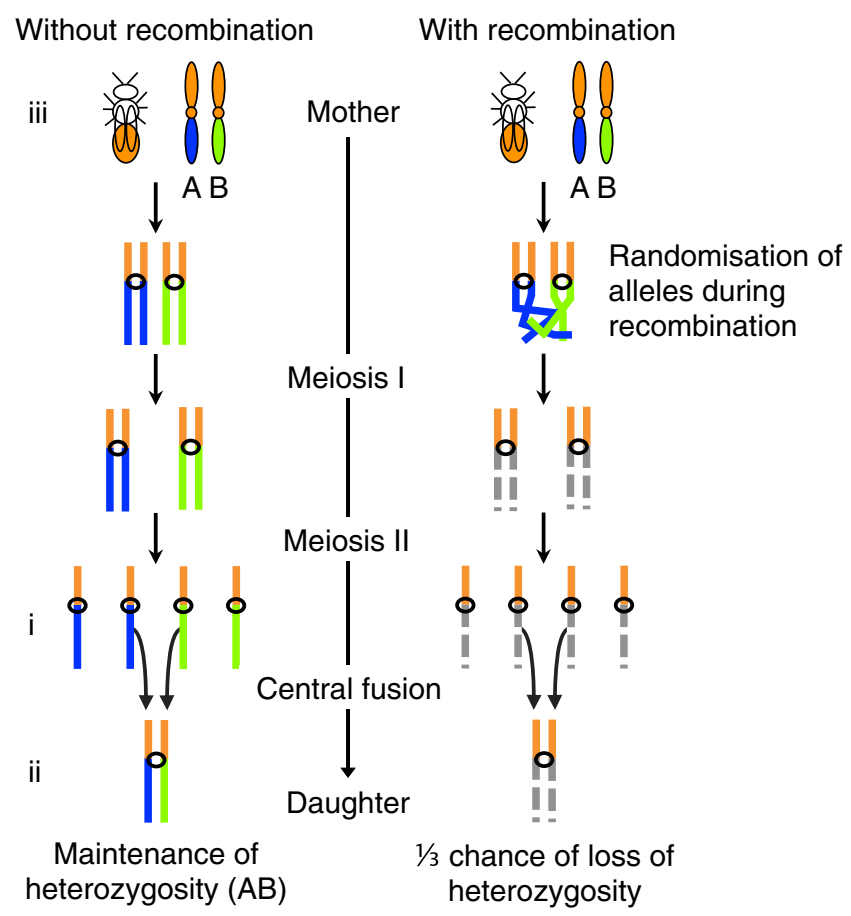

Figure 1 Automixis with central fusion. Meiosis occurs as normal resulting in four haploid pronuclei $(i)$. Pronuclei occupying the central position fuse for form the diploid zygote (ii). As this fusion is central, the pronuclei involved are descended from the two different homologous chromosomes (iii). In the absence of recombination, heterozygosity in the mother will be maintained in the daughter. When recombination occurs, alleles are randomised among the four pronuclei and as a result there is a $1 / 3$ chance that heterozygosity will be lost in the offspring. This is allocation of alleles to the central pronuclei is an example of sampling without replacement. If one of the central pronuclei carries an A allele, there is a $1 / 3$ chance that the other central pronucleus will carry the second A allele, and a $2 / 3$ chance that it will carry one of the two B alleles. If you do not believe us (many readers will not) try writing 'A 'on two bits of paper and 'B' on two other bits. Draw one piece of paper at random: this is the first central pronucleus. Let us pretend it is an A. Now, what is the probability that the second pronucleus you draw will also be an A?

Thelytoky dramatically increases the reproductive potential of the honey bee worker, resulting in competition between workers and worker patrilines (lineages of full-sister workers, sharing a father) (Moritz et al. 1996; Figure 3). This tendency has selected for traits related to reproduction and reproductive competition in Capensis workers (Greeff and Villet 1993). Capensis workers often have a welldeveloped spermatheca (a sperm storage organ found in queens), which is absent in workers of other honey bee subspecies (Hepburn and Crewe 1991; Phiancharoen et al. 2010). Furthermore, the Capensis worker has an average of 10-20 ovarioles per ovary (Ruttner 1977; Hepburn and Crewe 1990; Allsopp et al. 2003; Goudie et al. 2012a). In contrast, workers in arrhenotokous honey bee populations typically have far fewer ovarioles (Amdam et al. 2004; Oldroyd and Beekman 2008). Ovariole number in worker patrilines is heritable and highly variable (Goudie et al. 2012a). This suggests that certain patrilines dominate reproduction in Capensis.

The Capensis worker does not always limit herself to competing with her sisters over the production of new queens. Capensis workers are able to act as non-natal reproductive 

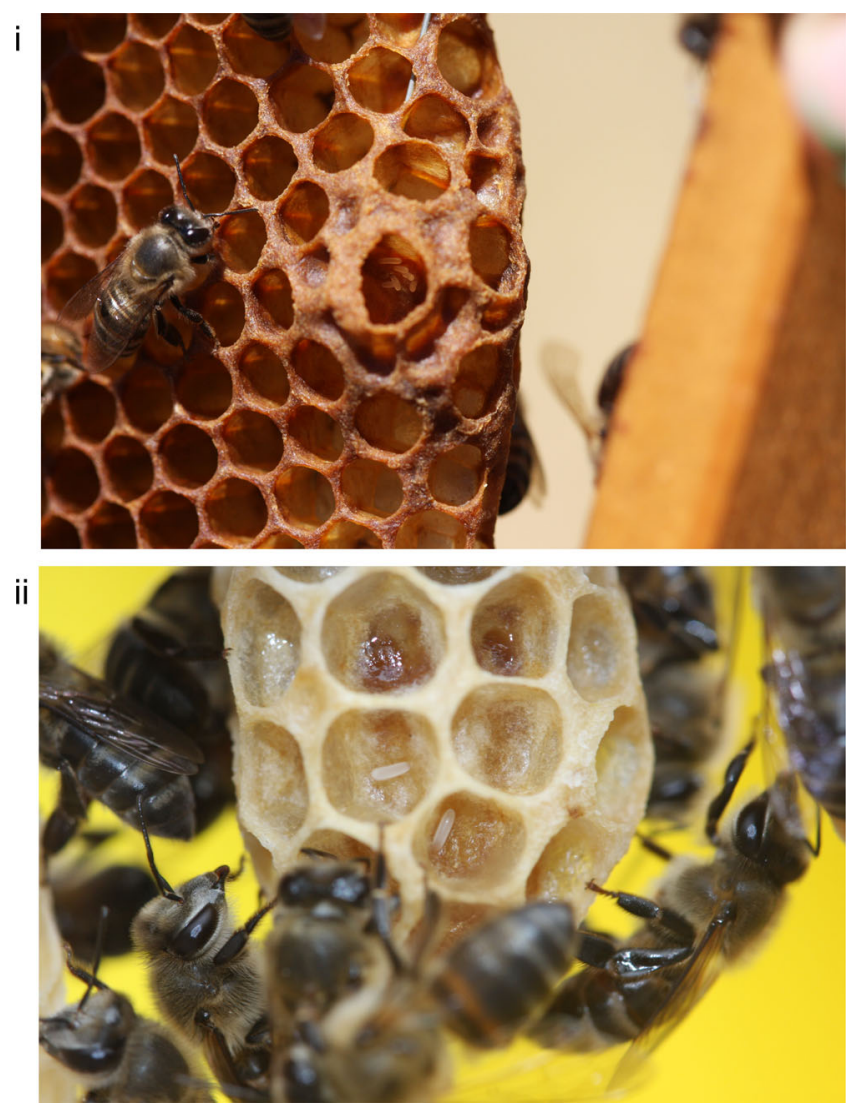

Figure 2 Worker laid eggs in a queenless Capensis colony. $i$ Egg laying workers focus around holes in the comb where queen cells are most likely to be built. $i i$ Worker laid eggs on the outside of an existing mature queen cell. Photos by B Oldroyd.

parasites, entering foreign colonies and laying eggs that may be raised as queens. Non-natal workers are responsible for the production of between 0.5 and $46 \%$ of new queens (Jordan et al. 2008; Allsopp et al. 2010; Holmes et al. 2010; Moritz et al. 2011). Variation in the degree of parasitism experienced by different colonies suggests that parasitism may be assisted by beekeeping methods (Dietemann et al. 2006a; Härtel et al. 2006). However, Holmes et al. (2010) observed rates of parasitism that were independent of apiary layout and distance between colonies. Furthermore, Neumann et al. (2001) found that Capensis workers disperse significantly more than other subspecies of $A$. mellifera and are more likely to parasitize queenless colonies. Whether or not movement of workers between colonies is an active process, as it seems to be in bumble bees (Blacher et al. 2013) and stingless bee queens (Wenseleers et al. 2011), remains open to question. However, it appears that once a non-natal worker enters a nest, she targets queen cells for oviposition. In colonies with high rates of parasitic queen production (38\%), only $6.9 \%$ of the workers were nonnatal (Jordan et al. 2008). Thus, the reproductive output of non-natal workers is disproportionally high, as is seen in colonies of the Asian species Apis florea (Nanork et al. 2005; Chapman et al. 2009) and Apis cerana (Nanork et al. 2007). This suggests the existence of specialised parasitic genotypes within the Capensis population. 


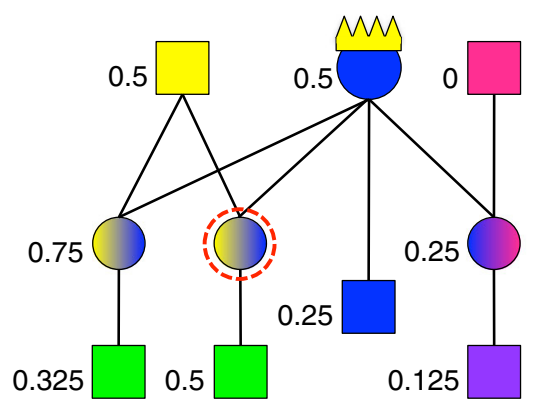

Arrhenotoky

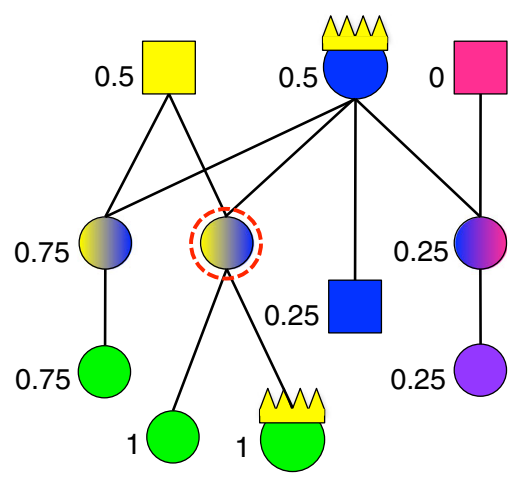

Thelytoky

Figure 3 The relatedness ( $r$ ) of a focal worker (red circle) to other individuals in a honey bee colony. Females are represented by circles and males by squares. The queen wears the crown, however, all females have the potential to be raised as a queen (although subfamilies differ in their likelihood of doing so). In a colony in which workers reproduce arrhenotokously, the focal worker is more closely related to the son of her mother $(r=$ $0.25)$ than the son of her half sister $(r=0.125)$ and so selection favours policing behaviour to suppress the reproductive efforts of other workers. In a colony in which workers reproduce thelytokously, the focal worker can produce daughters that are related to her by unity $(r=1)$. She can use this ability to produce daughters that might become queens, resulting in her effective genetic reincarnation as a queen. She is equally related to her sisters as she is to the thelytokous daughters of her sisters. In the same way, the queen is equally related to her daughters as she is to the thelytokous daughters of her daughters, and so it makes no difference to the colony as a whole if the new queen is produced sexually by the original queen or thelytokously by a worker. Therefore, selection for policing behavior is relaxed relative to arrhenotokous populations.

\subsection{The Capensis Clone}

By liberating the worker from reliance on a sexual queen, thelytoky has enabled the emergence of entirely asexual lineages of social parasites. On at least three occasions, two historic and one current, parasitic lineages have emerged as specialised reproductive parasites of the strictly arrhenotokous subspecies Apis mellifera scutellata (hereafter Scutellata; Martin et al. 2002).

While Capensis is confined to the southernmost tip of South Africa, Scutellata occupies the rest of the southern and most of central Africa (Hepburn and Radloff 1998; Figure 4). In 1990, a beekeeper moved approximately 200 commercial Capensis colonies across the stable hybrid zone that separates the two subspecies (Beekman et al. 2008; Allsopp and Crewe 1993) and into Scutellata range (Allsopp and Crewe 1993; Neumann and Moritz 2002). From here, Capensis workers drifted into (or perhaps invaded) the local Scutellata colonies, commenced laying and produced thelytokous daughters. One of these daughters founded a thelytokous lineage of clonal workers that has infested commercial Scutellata colonies ever since (Kryger 2001; Baudry et al. 2004; Oldroyd et al. 2011). Over the past 23 years, the Clone has been responsible for what became known as the 'Capensis Calamity' (Allsopp 1992; Neumann and Moritz 2002). While new beekeeping practices have reduced rates of transmission, the Clone lineage remains highly virulent and is still responsible for the loss of hundreds of commercial Scutellata colonies each year (Cobey 1999).

The invasion of Scutellata colonies by the Clone appears to be largely dependent on apicultural practices (Moritz 2002; Neumann and Hepburn 2002; Dietemann et al. 2006a). Clone infestation is observed at only low levels in the wild Scutellata population, and only when the wild colonies are in contact with domestic 


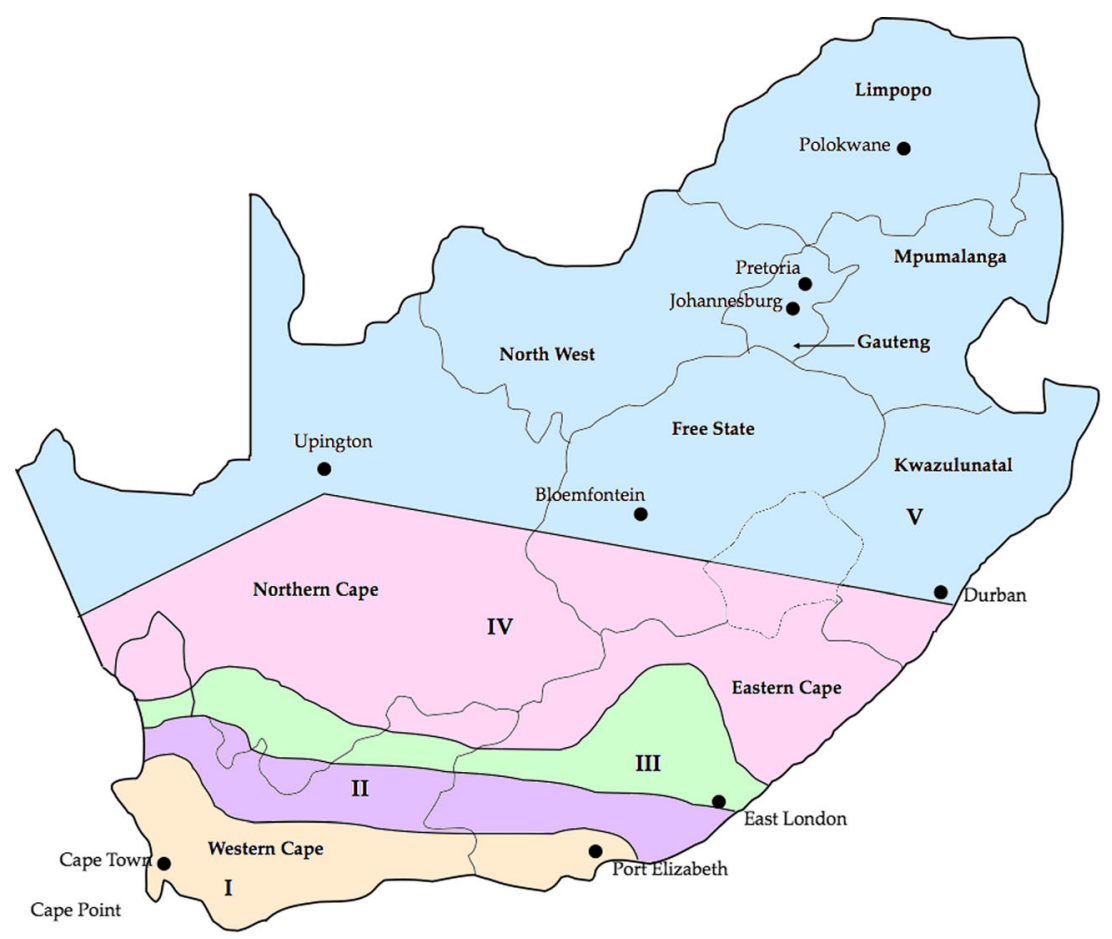

Figure 4 Map of South Africa (after Oldroyd et al. 2011), showing (I) the natural range of Capensis, (II) the stabile hybrid zone between Capensis and Scutellata and (III) the South African distribution of Scutellata, over much of which the Clone can now be found.

colonies (Härtel et al. 2006). Clones have difficulty invading Scutellata colonies without assistance (Moritz et al. 2008). However, once a Clone has successfully established in a host colony, the colony's downfall is all but inevitable.

When Clones enter a Scutellata colony, they activate their ovaries and produce queen-like mandibular gland secretions despite the presence of the host queen (Härtel et al. 2011). Clones thus establish themselves as pseudoqueens, and are tended to by host workers as if they were the rightful Scutellata queen of the colony (Figure 5). The host queen is soon lost as a result of lethal fighting (Moritz et al. 2003) and pheromonal competition (Dietemann et al. 2006b; Moritz et al. 2004). The presence of reproductively active pseudoqueens may suppress the development of later Clone offspring, resulting in the establishment of dominance hierarchies (Härtel et al. 2011), with only a small number of Clones reaching reproductive dominance within the host colony (Martin et al. 2002). However, despite the suppression of reproduction in many Clone offspring, they rarely engage in work such as foraging or brood care (Martin et al. 2002).

Clone larvae manipulate host nurse workers, eliciting greater levels of feeding, with food that is more similar in composition to that of royal jelly, than the fare normally provided to mere workers (Calis et al. 2002). The resultant Clones have more queen-like characteristics than normal workers, including shorter developmental time, higher weight, larger spermatheca and larger number of ovarioles, while worker characteristics such as pollen combs and pollen baskets on their hind legs are suppressed (Wirtz and Beetsma 1972; Calis et al. 2002). Thus, the host colony is soon over run with Clone pseudoqueens and their offspring, which only adds to the burden of useless reproductive workers already afflicting the host colony. With time, the number of host workers dwindles and the colony inevitably 


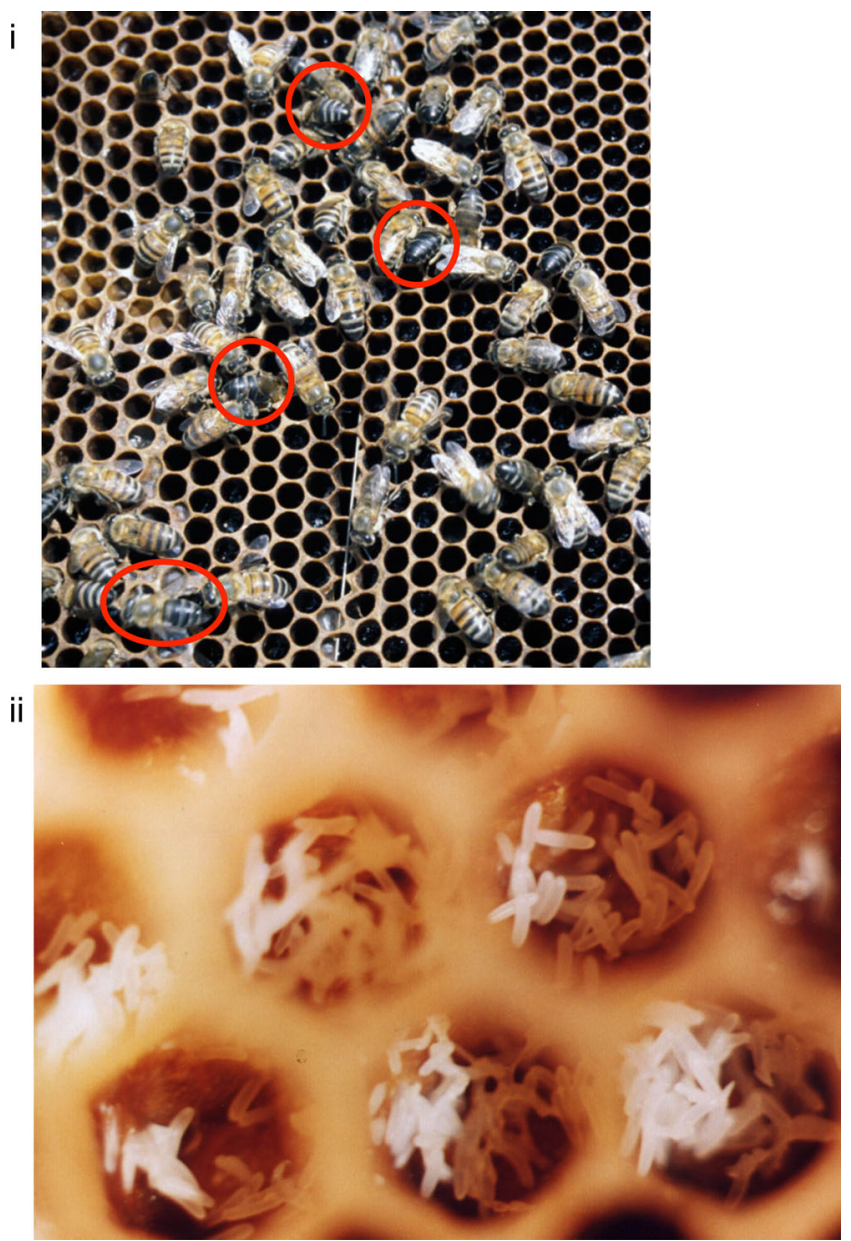

Figure 5 Reproductive Clones in a host Scutellata colony. $i$ Darker-bodied Clones (circled in red) are tended to by host workers as if they were host queens. $i i$ In the later stages of invasion, Clones lay dozens of eggs in host brood cells that should only hold one. Photos by B Oldroyd.

declines and collapses (Allsopp and Crewe 1993; Hepburn and Allsopp 1994).

\subsection{A social cancer}

The analogy of the honeybee colony as a 'super organism' is well established and compelling (e.g. Wheeler 1911; Seeley 1989; Moritz and Southwick 1992; Moritz and Fuchs 1998; Amdam and Seehuus 2006; Hölldobler and Wilson 2008; Johnson and Linksvayer 2010; Seeley 2010; Page 2013). The queen can be compared to the gonads of a multicellular organ- ism, supported by the somatic cells, a role played by workers. Somatic cells do not reproduce themselves, instead they make up the larger whole that enables the gametic cells (drones and virgin queens) to survive and propagate into the next generation. Multicellularity has been able to evolve because the cells that make up the multicellular organism are identical, having propagated from a single zygote. Similarly, worker bees forgo direct reproduction in favour of supporting the reproductive efforts of their queen, and through their work, allowing the colony to survive and send forth reproductive swarms. Like 
the cells of a multicellular organism, the individuals of a honey bee colony are related and so kin selection theory provides an explanation for how individuals could evolve to sacrifice direct reproduction in favour of propagating their genes through the reproductive success of related individuals (Hamilton 1964).

Cancer occurs in a multicellular organism when mutations in somatic cells result in cellular replication without restraint (Weinberg 1998). Similarly, in the honey bee colony, cheater workers regularly emerge that abandon reproductive self-restraint and reproduce at the expense of the colony (Barron et al. 2001; Beekman and Oldroyd 2008b; Châline et al. 2002; Holmes et al. 2013; Montague and Oldroyd 1998; Oldroyd et al. 1994). In the Capensis population, cheating occurs when daughters of the colony lay eggs in queen cells (Jordan et al. 2008; Allsopp et al. 2010; Holmes et al. 2010; Moritz et al. 2011). Thus, these workers can be compared to cancerous cells in a multicellular organism. This is taken a step further, when reproductive parasites invade non-natal colonies and begin competing over reproduction. We might view non-natal reproductive parasitism in the Capensis population as a kind of transmissible cancer. This is not without precedent in multicellular organisms. (See for example, the contagious facial tumours of the Tasmanian Devil Sarcophilus harrisii and the sexually transmitted cancer of domestic dog Canis lupus familiaris; Siddle and Kaufman 2013.)

The Clone is an extreme example of this phenomenon, a self-propagating 'cancerous' lineage that reproduces outside any constraint imposed by the colony, while taking full advantage of the resources it provides (Oldroyd 2002). The Clone goes further than most cancers of multicellular organisms, for it is sometimes able to survive the destruction of its host and transfer to another.

Moritz et al. (2008) regard the Clone as parasite with high virulence and low transmissibility, resulting from shortsighted within-host selection (Levin 1996). Under this model, the most virulent parasitic genotype outcompetes less virulent genotypes during the infection phase of the invasion, before horizontal transmission occurs, resulting in a selection of a lineage with high virulence but low transmission (Bull 1994).

As predicted by a scenario of 'short-sighted evolution', rates of horizontal Clone transmission were not only undetectably small in a source-sink experimental setup without apicultural intervention, they were much lower than rates of transmission of Capensis workers taken from the endemic Capensis range (Moritz et al. 2008).

The Clone emerged after the movement of over 200 Capensis colonies into the Scutellata range (see above and Allsopp and Crewe 1993). Assuming that each colony comprised maybe 20,000 workers, made up of at least 20 patrilines (Palmer and Oldroyd 2000), the truckload of colonies comprised approximately 4 million worker genotypes and at least 4,000 patrilines. From these genotypes, a single Clonal lineage emerged, one selected for high virulence within Scutellata host colonies. Clonal reproduction then enabled this lineage to endure for generations, with its virulent genotype unchanged by sexual recombination.

\subsection{Maintenance of heterozygosity in the Clone}

Thelytoky in Capensis (automixis with central fusion, see above) carries the inherent feature of loss of heterozygosity. Specifically, wherever recombination exchanges genetic material between chromosomes, there is a $1 / 3$ chance that a locus that is heterozygous in the mother will become homozygous in offspring (Pearcy et al. 2006; Oldroyd et al. 2008; Engelstadter et al. 2010) (Figure 1). Therefore, ongoing generations of thelytoky should result in population-wide homozygosity at all loci that are free to recombine (Goudie et al. 2012b). Yet empirical studies have revealed levels of heterozygosity in the Clone that are remarkably high (Baudry et al. 2004; Neumann et al. 2011; Oldroyd et al. 2011).

Historically, the unexpectedly high levels of heterozygosity observed in the Clone were attributed to a reduction in meiotic recombination 
(Moritz and Haberl 1994; Baudry et al. 2004). However, Goudie et al. (2012a) demonstrate that a reduction in recombination is insufficient to explain current levels of heterozygosity. Loss of heterozygosity in a thelytokous lineage is cumulative. Heterozygous mothers produce homozygous daughters at $1 / 3$ the rate of recombination, while homozygous mothers produce homozygous offspring exclusively (Engelstadter et al. 2010; Goudie et al. 2012b). Therefore, for any realistic level of recombination (whether reduced or not), homozygosity will inevitably accumulate. After 20 years of exclusive thelytokous reproduction, reduction in recombination cannot explain the maintenance of heterozygosity in the Clone at any but the most centromeric loci where recombination is exceedingly rare (Goudie et al. 2012b).

Maintenance of heterozygosity in the Clone can instead be explained by selection against homozygous recombinants at genes that are subject to heterozygote advantage (Oldroyd et al. 2011; Goudie et al. 2012b). A key example of the effects of this kind of selection is the maintenance of heterozygosity at the complementary sexdetermining locus $(c s d)$. Honey bees must be heterozygous at the $c s d$ for the female phenotype to be expressed, while haploid males are hemizygous. Homozygosity at the csd results in the production of a diploid male. Diploid males are inviable because they are eaten at early larval stages (Woyke 1963; Beye et al. 2003). Therefore, the csd locus is homozygous lethal, and any Clone offspring in which recombination results in homozygosity at this locus will be lost to cannibalism, thus maintaining heterozygosity at the $c s d$ in perpetuity.

The $c s d$ is a locus with known heterozygous advantage (overdominance). However, heterozygosity is observed throughout the Clone genome at loci that are unlinked to $c s d$ and presumed to be selectively neutral. How? There is now strong evidence that heterozygosity is maintained throughout much of the Clone's genome by selection acting on overdominant loci (Goudie et al. 2012b, 2014). These putative overdominant loci are theorised to be in linkage disequilibrium with the marker loci that are observed to be heterozygous. In support of this theory, the frequency of homozygosity is significantly higher in Clone eggs than in it is in larvae and pupae, at both the $c s d$ and a range of neutral markers unlinked to the $c s d$ (Goudie et al. 2012b). These analyses show that recombination occurs at normal or near-normal rates in the Clone, resulting in the production of homozygotes, including diploid males. However, these recombinants are rapidly removed from the population, permanently retaining heterozygosity in the surviving Clones (Goudie et al 2012a, 2014).

Goudie et al. (2014) mapped patterns of zygosity along chromosomes III and IV in the Clone to determine the evolutionary outcome of recombination and selection. Loss of heterozygosity in a Clonal lineage is non-reversible, and a single recombination event will result in loss of heterozygosity at all markers located in a telomeric direction from the point of chiasmata, unless a second, concurrent recombination event results in restoration of heterozygosity (Figure 6). Yet in the Clone, complete loss of heterozygosity occurs in restricted regions, with subsequent restoration of heterozygosity in telomeric regions (Figure 7). This pattern of hetero/homo-zygosity along chromosomes suggests that overdominant genes located in the telomeric regions maintain heterozygosity, and indeed this pattern is observed at the csd on chromosome III. Goudie et al. (2014) therefore suggested that there are at least three overdominant genes maintaining heterozygosity on chromosome $\mathrm{IV}$, and four genes (including the $c s d$ ) that maintain heterozygosity on chromosome III.

While low rates of recombination were once thought to maintain heterozygosity during thelytoky, growing evidence suggests that usually high rates of recombination may in fact shape the evolution of the Capensis genome under thelytoky. The honey bee genome is characterised by very high rates of recombination (4 times higher than most other taxa and 20 times higher than in humans) (Beye et al. 2006; Solignac et al. 2007). Furthermore, the honey bee has low levels of positive interference (Solignac et al. 2004), i.e. one recombination event does not suppress the probability of a second recombination event occurring nearby. Therefore, high rates of double recombination events within relatively small genetic distances are not unexpected in a honey bee genome. It is 


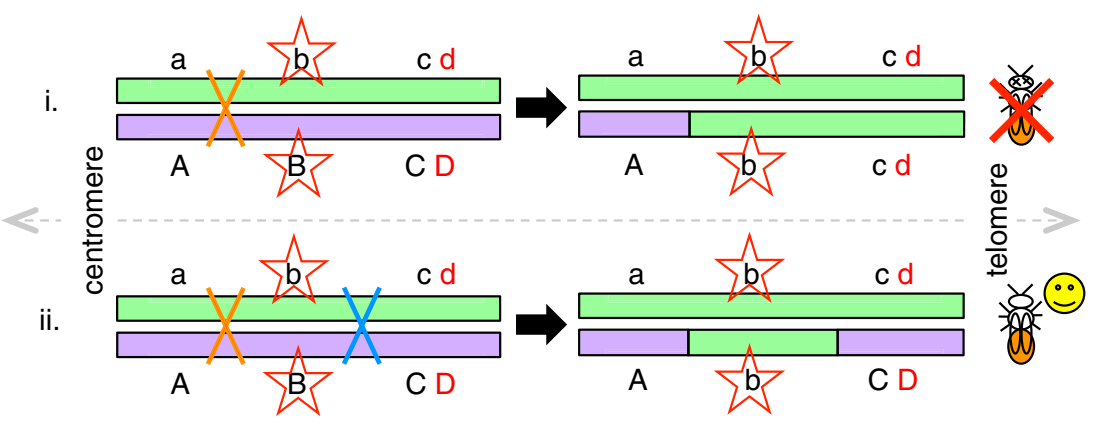

Figure $6 i$ A single recombination event (orange $X$ ) will result in loss of heterozygosity at all telomeric markers $(b, c, d$ ). If a locus $d$ (here linked to the marker $c$ ) is selectively overdominant, such a recombinant genotype will be selected against. $i i$ Loss of heterozygosity at the marker B will only be observed if it is accompanied by a second, concurrent 'rescue' recombination event (blue X) which restores heterozygosity at locus D which is assumed to be under overdominant selection for heterozygosity.

these double-recombination events that are required to generate the genotypes that allow selection to maintain heterozygosity at isolated overdominant loci under selection, while heterozygosity is lost along the majority of the chromosome (above, Goudie et al. 2013).

High rates of recombination and positive interference in the honey bee has recently been linked to a high rate of gene conversion without crossover (non-crossover) events (Bessoltane et al. 2012). In fact, recombination events are more frequent in the honey bee genome than crossover events. Allelic gene conversion (the replacement of one allele with another at the same locus) can result in loss of heterozygosity during thelytoky. However, nonallelic gene conversion (the replacement of an allele with another from a different locus) could in fact increase genetic diversity, even in a clonal population. It is thus possible that gene conversion may counter loss of heterozygosity during thelytoky. The degree to which gene conversion occurs in Capensis remains to be established, as does the impact that gene conversion may have on the already-documented selective processes that retain heterozygosity in the Clone (Goudie et al. 2012b, 2013).

\subsection{Clone drones}

Recent evidence has shown that Clones do not reproduce exclusively via thelytoky, as had previ- ously been assumed (Lattorff et al. 2005). Haploid male eggs were detected in the brood of Clone workers, at a frequency of one in eight (Goudie et al. 2012b). In larvae of the Clones, the frequency of haploid males dropped fivefold relative to eggs, suggesting strong selection against Clone males, though this selective removal may have arisen as a result of haploid male eggs being laid in worker cells. Preliminary evidence now suggests that a few Clone drones survive to maturity. A single adult haploid male carrying Clone alleles at all loci tested $(n=9)$ was detected among 78 black drones collected from Clone-infested Scutellata colonies (Goudie et al., unpublished data). Thus, despite the apparent low frequency of adult Clone drones, our singular example (thus far) shows that some haploid males produced by the Clone lineage are able to reach maturity. It is therefore possible that Clone drones mate with Scutellata queens, resulting in introgression of Clone alleles in to the Scutellata population. This further raises the possibility of contagious parthenogenesis (Engelstadter et al. 2010) in which the rare production of males by clonal lineages leads to the transmission of alleles conferring asexuality into otherwise sexual populations.

\subsection{The genetics of thelytoky in Capensis}

Thelytoky in Capensis is thought to be controlled by a single recessive locus termed thelytoky 


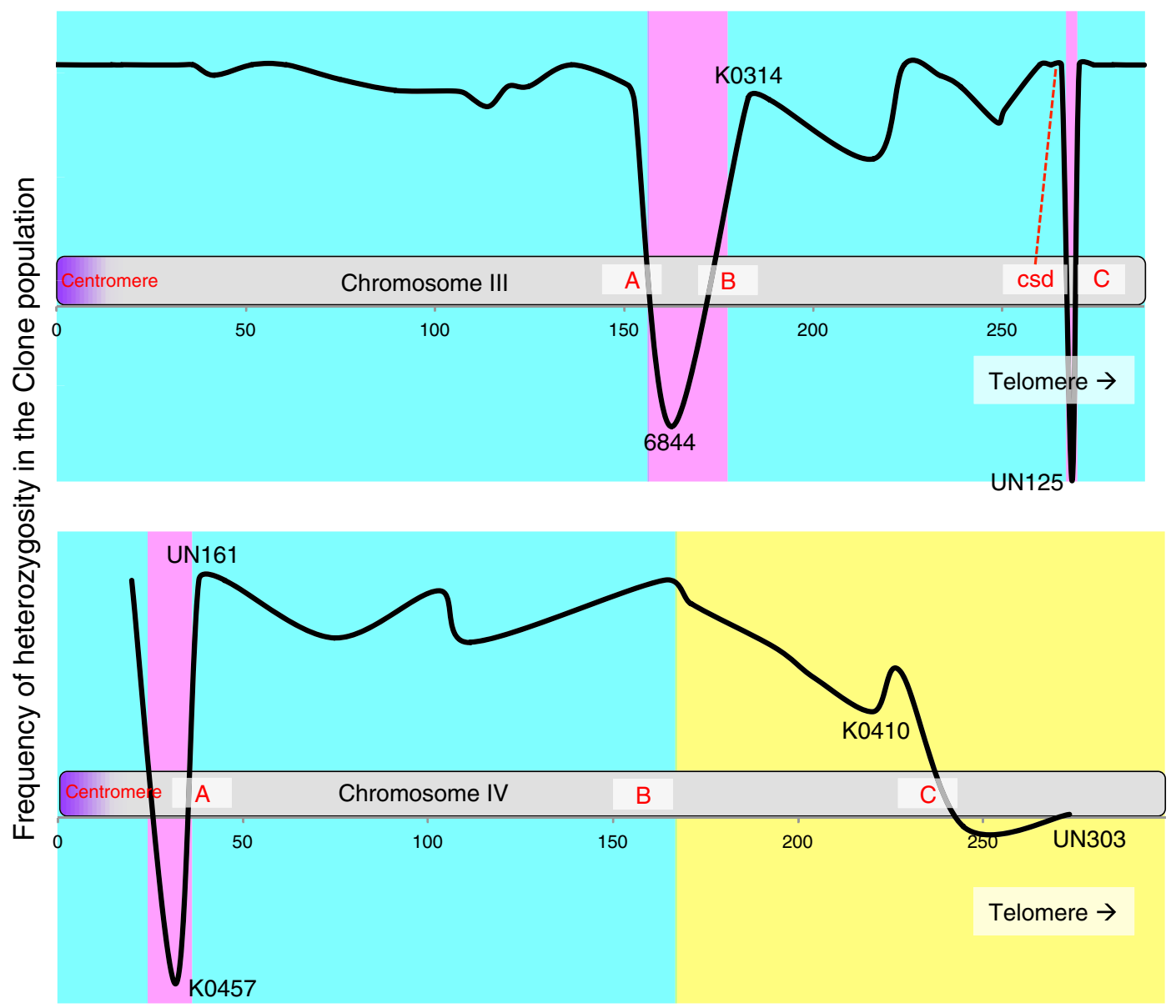

Figure 7 The pattern of zygosity along chromosomes III and IV, of the Clone incorporating a descriptive model for the maintenance of heterozygosity (Goudie et al 2013). Heterozygosity is maintained in blue regions by linkage to a heterozygosity-maintaining factor (HMF): the centromere, the $c s d$, or putative genes under overdominant selection $(a, b, c)$. As we move down the chromosome towards the telomere, heterozygosity is lost in purple regions as a result of a recombination event at points telomeric to a HMF, but restored by a second, concurrent recombination which occurred before the next HMF (e.g. heterozygosity is lost after the overdominant gene A on chromosome III, but restored before the gene B). In the yellow region of chromosome IV heterozygosity declines gradually, suggesting either incomplete selection, or the escape from selection by some sublineages due to double recombination events that were undetected in this analysis.

(th) (Lattorff et al. 2005). However, backcross experiments suggest that while th plays a major role in determining the thelytoky phenotype, the genetic basis of thelytoky may be a little more complex than is currently appreciated (Oldroyd et al., unpublished data). Furthermore, the frequent production of haploid eggs by Clones (with the putative genotype $t h, t h$ ) suggests that the th locus may not have complete expressivity (Goudie et al. 2012b). Alternatively, errors in thelytoky may be frequent in this lineage.

Under the single gene model for thelytoky, it has been proposed that differential splicing of the transcription factor $C P 2$, a homolog for the Drosophila transcription factor gemini, results in the development of the thelytokous phenotype (Jarosch et al. 2011). Splice forms of CP2 in Capensis are more similar to those of sexual 
queens then arrhenotokous workers in other subspecies. Jarosch et al. (2011) suggest that thelytoky in Capensis may be determined by the lack of a short splice enhancer motif. Knockdown of this motif in arrhenotokous workers results in rapid ovary activation, which is one of a number of features that characterise the highly reproductive Capensis worker phenotype.

\subsection{Capensis and sex}

Capensis, and in particular the Clone, provides a valuable model with which to investigate the genetic and evolutionary consequences of thelytokous parthenogenesis, providing unique insights into the evolutionarily tradeoff between sex and asexuality that drives the distribution of reproductive strategies among animal taxa.

Sexual reproduction is the predominant form of reproduction among multicellular organisms (White 1984; Suomalainen et al. 1987), yet the near ubiquity of sexual reproduction remains an enduring evolutionary mystery. Many potential benefits of sex have been proposed and investigated (see Otto and Gerstein 2006; Engelstadter 2008). These seek to deal with the fundamental question of how an allele imparting sexual reproduction could outcompete an allele causing asexual reproduction when sexuality reduces the reproductive potential of a population by a factor of 2 , as a consequence of the production of males that do not themselves reproduce (Maynard Smith 1978).

In Capensis, we observe three unique female reproductive phenotypes, the queen, the worker and the Clone. Each of these utilise the same underlying genotype, however, the interplay of life history with the costs and benefits of sex and asexuality has resulted in the evolution of distinctly different reproductive strategies.

\subsection{The queen}

At first, it appears perplexing that the Capensis queen forgoes thelytoky. Thelytokous reproduction would allow a Capensis queen to produce daughter queens that are related to her by unity ( $r$ $=1$ ). Like certain thelytokous ant species, she could perhaps continue to employ sexual reproduction to produce workers (Cataglyphis cursor, Pearcy et al. 2004; Wasmania auropunctata, Fournier et al. 2005; Vellonhovia emeryi, Kobayashi et al. 2008), gaining the best of both evolutionary worlds: effective genetic immortality in her reproductive offspring and genetic variability with its associated benefits (Jones et al. 2004; Mattila and Seeley 2007; Oldroyd and Fewell 2007; Seeley and Tarpy 2007) in her workers. Thelytoky is a very real evolutionary option for a Capensis queen. A virgin Capensis queen can reproduce both thelytokously and arrhenotokous when induced to start laying by double narcosis with $\mathrm{CO}_{2}$ (Allsopp and Crewe 1993; Oldroyd et al. 2008). Yet, despite the potential benefits, there is no evidence that mated Capensis queens ever lay thelytokous eggs (Jordan et al. 2008; Holmes et al. 2010; Moritz et al. 2011), providing strong evidence that for the Capensis queen, the costs of thelytoky outweigh the costs of sex.

A honey bee colony reproduces via the production of drones and swarms. The queen leaves the colony heading a swarm comprised of about half the workers, leaving behind a small number of queen cells containing her queen-destined daughters. One of these daughters will inherit the original colony, while one or two others may head secondary swarm that has a lower survival than the first (Hepburn and Radloff 1998; Seeley 2010). Thus, queens trust their reproductive futures in a tiny number of daughter queens. Any reduction in larval viability associated with thelytoky may therefore have a substantial impact on a queen's fitness (her larva may be usurped by that of a worker), which is compounded by the absence of the many benefits associated with sexual reproduction (Otto and Gerstein 2006).

A queen that produces daughter queens asexually and daughter workers sexually would come into direct conflict with her worker daughters. She would share twice as many alleles with her own thelytokously-produced queen daughter $(r=1)$ than she would with the thelytokously-produced daughters of her sexually produced worker $(r=0.5$; 
Figure 8). A queen that produces both worker and queen offspring thelytokously eliminates this competition, but in the process, massively reduces the genetic diversity of her work force and so potentially the fitness of the colony she relies on to raise her reproductive offspring (Figure 8). However, a sexual queen is equally related to her sexual daughter as she is to her thelytokouslyproduced granddaughter (Figure 8). Therefore, provided her workers are working (and not just breeding, Hillesheim et al. 1989), a queen is predicted to be indifferent to the production of new queens by natal workers (Greeff 1996; Beekman and Oldroyd 2008a).

\subsection{The typical Capensis worker}

Thelytoky massively increases the reproductive potential of a Capensis worker, enabling her to produce diploid daughters and to compete with her mother and fellow workers over the production of new queens. Not only does thelytoky increase the reproductive potential of the Capensis worker, it fundamentally alters the kin structure of a Capensis colony relative to that of an arrhenotokous colony, eliminating, or greatly reducing, the selective pressures that normally drive workers to suppress the reproductive proclivities of their worker sisters (Greeff and Villet 1993; Moritz et al. 1999). Honey bee queens are extremely polyandrous (Palmer and Oldroyd 2000) and as a result workers within a colony are mainly half sisters. Thus, in an arrhenotokous colony, a worker is more closely related to the sons of her mother $(r$ $=0.25)$ than to the sons of a fellow worker $(r=$ $0.125)$. While a worker might benefit from producing her own sons $(r=0.5)$, collectively workers prefer to raise the sons of their mother (Ratnieks 1988). As a result, worker policing has evolved, where workers eat eggs that have not been laid by the queen (Ratnieks and Visscher 1989). In contrast, Capensis workers can benefit immensely from personal reproduction, while the queen and other workers are largely indifferent to it, provided it does not unduly reduce colony productivity (Beekman et al. 2002, 2009; Greeff and Villet 1993; Moritz et al. 1999; Pirk et al. 2002). While the Capensis worker still benefits more from producing her own offspring than raising the offspring of another, she is indifferent to whether the offspring of other females are produced by workers or queens. Thus, instead of policing, directed worker competition is expected to evolve, and is observed (Jordan et al. 2008; Moritz et al. 1996, 2011).

As described above, thelytoky incurs a cost in Capensis workers; a 1/3 loss of heterozygosity per generation for any locus that is free to recombine. So, for example, $1 / 3$ of eggs laid by Capensis workers should be inviable diploid males. However, the reproductive Capensis worker takes advantage of reproductive opportunities that are otherwise unavailable. Unlike the Capensis queen, sex is not an evolutionary option for the worker, while thelytoky provides a worker with a window of opportunity to be genetically reincarnated to the queen phenotype. A worker's thelytokously-produced daughter queen subsequently reproduces sexually, and so the cost of thelytoky in the worker is only paid over a single generation; loss of heterozygosity does not compound once the worker is reincarnated as a queen.

The thelytokous worker has everything to gain and little to lose though thelytokous parthenogenesis, particularly when frequencydependent selective forces maintain 'cheater' parasitic lineages at low levels that do not jeopardise the stability of the eusocial colony (Hillesheim et al. 1989).

\subsection{The Clone}

The introduction of highly reproductive Capensis workers to Scutellata colonies enables the emergence of asexual lineages that are completely liberated from reliance on a sexual queen for their vicarious reproduction. However, for thelytoky to endure over evolutionary time, a cost must be paid. Maintenance of heterozygosity by selection requires the removal of homozygous recombinant offspring each and every generation. To be specific, heterozygosity will be maintained at a locus provided that the number of homozygotes 

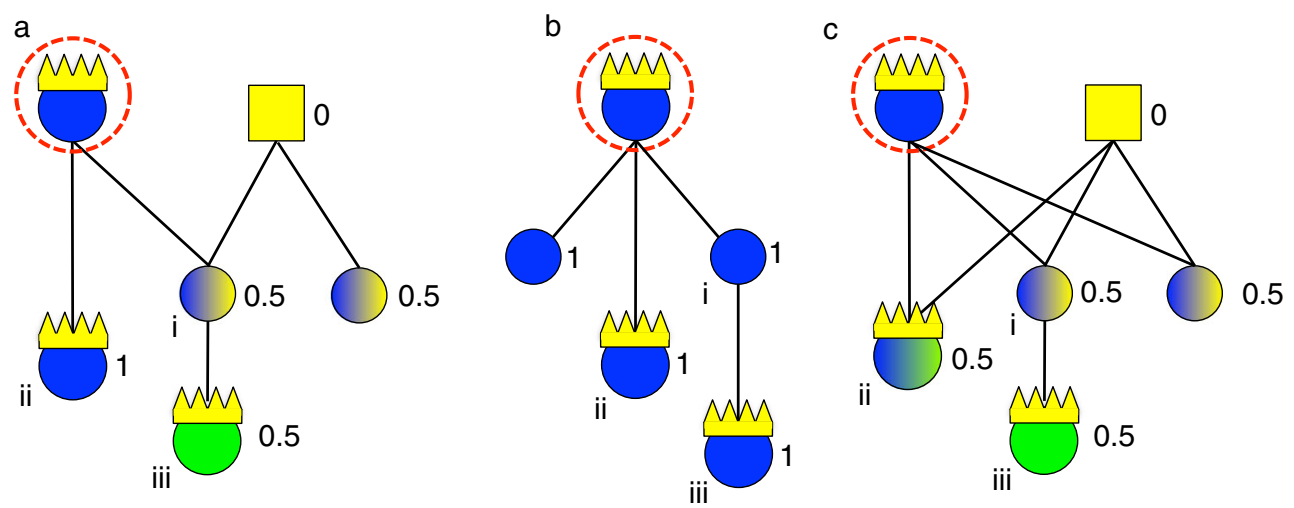

Figure 8 The three evolutionary options for Capensis queens. The queen in each pedigree is circled in red, all values refer to her relatedness $(r)$ to each individual. a A queen that produces workers sexually (ii) and new queens thelytokously (ii) maximises her relatedness to her queen daughters while maintaining genetic diversity in her worker force. However, she will come into conflict with her daughters. She is twice as related to her own queen daughter (ii) as she is to a worker-produced queen (iii). b A queen that produces both worker (i) and queen (ii) daughters thelytokously avoids competition. She is equally and maximally related to her own queen daughter (ii) as she is to a worker-produced queen (iii). However, she has much reduced genetic diversity in her colony, which may suffer from reduced disease resistance and less efficient task allocation. c A queen that produces both worker $(i)$ and queen (ii) daughters sexually also avoids conflict with her female offspring, while maintaining genetic diversity in the colony In this scenario, which is what we also see in reality, the queen only shares half her alleles with her queen daughters. However, when we take into account the evolutionary alternatives (a and $\mathbf{b}$ ), we see that this strategy maximises queen fitness.

being removed by selection is equal to or greater than the number being produced by recombination (Goudie et al. 2012b). Therefore, for a thelytokous lineage such as the Clone to endure, the benefits of thelytoky must outweigh the per-generational cost in reduced viability, which is necessary to maintain the integrity of the clonal genome. We (Goudie et al. 2012b) proposed that the parasitic life history of the Clone does indeed make it ideally suited to enduring this cost.

During an invasion, Clone workers lay a massive number of eggs. Eventually, brood cells that should only hold one egg become packed with dozens of Clone progeny (Figure 5). Only a tiny proportion of these eggs can ever be expected to hatch, let alone emerge as an adult, survive colony collapse and continue the invasive cycle (Martin et al. 2002; Neumann and Hepburn 2002). And for a Clone, the production of these eggs is cheap; she is waited on, wing and tarsis, by her hosts, taking no part in non-reproductive tasks, such as foraging and brood care. Any of her offspring that emerge are abandoned to the care of their hosts, from whom Clones elicit level of attention normally reserved for royalty (Beekman et al. 2000; Allsopp et al. 2003). A Clone can therefore dedicate her life to producing thelytokous eggs, in the hope that some will reach maturity. High rates of reproduction, low maternal investment and concordantly high mortality are an inherent part of the Clone's parasitic reproductive strategy-when the vast majority of eggs cannot be raised to maturity, it hardly matters if many of them are inviable.

\subsection{Of queens, workers and Clones}

While thelytoky imposes high costs, it allows the Clone to exploit a new niche that would otherwise be unavailable, that of social parasitism. Parasitism is both the means by which the Clone benefits from going without sex, and the means in which it is able to endure the costs of thelytoky. Workers from the sexual Capensis population, in contrast, play the odds, giving thelytoky a go 
because they have no other avenue for direct reproduction, while still being relatively assured of the indirect benefits of a eusocial existence. In the queen, we see the more standard outcome to the evolutionary tradeoff between sex and asexuality, the costs of thelytoky may be too high a price when the queen's reproductive future, and that of the colony, is vested in a small number of potentially reproductive daughters.

Using Capensis and its Clone as a model, we suggest that the costs and benefits of sex and asexuality should be considered in a more conditionally than is often the case. The specific life history of a population, and the outcomes of the mode of thelytoky it employs, must be examined to account for where costs and benefits are imposed, and where they can be endured.

\section{THE EVOLUTION OF THELYTOKY IN $A P I S$}

\subsection{Thelytoky in Apis more broadly}

Capensis appears to be the only honey bee in which thelytoky is ubiquitous. However, Mackensen (1943) reported that approximately one percent of eggs produced by virgin queens of the Italian (Apis mellifera ligustica) and Caucasian (Apis mellifera caucasica) subspecies were female, the result of thelytokous parthenogenesis. (Mackensen's experimental queens had been exposed to double $\mathrm{CO}_{2}$ narcosis, which induces oviposition in honey bee queens, normally resulting in the production of arrhenotokous males.) The low frequency of thelytokous reproduction may well be the result of errors in arrhenotokous parthenogenesis. However, the regularity with which thelytokous offspring was observed by Mackensen (1943) suggests that thelytoky is a threshold character that can be released with relatively small genomic, and perhaps environmental, changes.

This conjecture is supported by the frequency with which thelytokous reproductive systems are being identified in another taxa of eusocial Hymenoptera. Thelytoky is relatively common in ants (Rabeling and Kronauer 2013) and the number of known thelytokous ant species has dramatically increased over the last few years, as more species are investigated with molecular techniques. Importantly, thelytoky in ants appears to be associated with invasive life histories (Rabeling and Kronauer 2013).

While not a honey bee, the solitary little carpenter bee Ceratina dellatorreana has been reported to reproduce thelytokously. As with many ants, thelytoky in the $C$. dellatorreana was observed in an invasive population, where it is hypothesised to have facilitated its introduction (Daly 1966). However, no further information is available on $C$. dellatorreana.

It appears very possible that more thelytokous bees are waiting to be discovered. Even wellstudied populations in which both males and females are present can be producing thelytokous females that are not detectable until we look for them explicitly, usually with molecular techniques.

\subsection{Thelytoky in $A$. cerana}

Evidence is currently accumulating that indicates that another species of honey bee, the Asiatic honey bee $A$. cerana, reproduces thelytokously (Holmes, unpublished data).

In recent years, an invasive population of $A$. cerana was identified in Queensland, Australia (Koetz 2013). This population was probably founded by a single reproductive swarm, and as such the population has limited genetic diversity. We hypothesise that thelytoky may have enabled the successful establishment of this invasive population. A disturbing possibility is that interspecific matings between $A$. cerana males and $A$. mellifera queens may induce thelytoky in $A$. mellifera queens (unpublished data).

\subsection{The evolution of thelytoky in Capensis}

Thelytoky may have evolved to be ubiquitous in Capensis during periods of the Pleistocene in which rising sea levels isolated the Cape Peninsula from the rest of the African continent (Ruttner 1977). It was once feared that the world's only known thelytokous bee would be overrun by the more aggressive and widespread Scutellata subspecies (a.k.a. the African killer bee; Ruttner 
1977). This fear is ironic in hindsight, given that we now know that Scutellata comes off second best when bought into contact with Capensis. In reality, a stable hybrid zone that neither subspecies is able to cross without human intervention (Beekman et al. 2008) now separates the two populations. Hybrid or mixed colonies of Capensis and Scutellata are assumed to suffer from reduced fitness (Beekman et al. 2008, 2012), though evidence for this hypothesis is currently lacking. Scutellata drones and virgin queens may outcompete Capensis at mating leks. However, even low frequencies of Capensis genotypes within a mixed subspecies colony is expected to result in a misallocation of resources by easily duped Scutellata workers, leading to the production of more reproductive Capensis workers, and a breakdown in regulation of worker reproduction (Beekman et al. 2008).

It has been hypothesised that thelytoky in Capensis originally evolved in response to high rates of queen loss on the windy and often inclement Cape Peninsular (Tribe 1983). Thelytoky does indeed provide Capensis with the means to produce a new queen when arrhenotokous subspecies might fail. However, given the global range of the honey bee, it seems highly unlikely that any environmental conditions experienced by Capensis are so unique that they alone have driven the evolution of such a distinctly divergent reproductive strategy.

We suggest that the evolution of thelytoky in Capensis was facilitated by genetic drift in a small, isolated population. While queen replacement may have played a role in selecting for thelytoky, a range of other factors would have been required for thelytoky to become ubiquitous in the population. Even assuming that thelytoky occurs at low frequency in otherwise arrhenotokous honey bee populations, workers laying thelytokous eggs in drone cells run into a genetic dead end, because these eggs will never develop to queens. Thus, thelytoky would not be selected for until such time as it co-occurs with a heritable behavioural variant in which workers target their reproductive efforts to queen cells. Furthermore, thelytoky emerging from a background of worker arrhenotoky does so in an environment of intense worker policing (Ratnieks 1988). Selection to reduce worker policing will not occur until after thelytoky has become ubiquitous. Thus, policing acts as an evolutionary barrier, reducing or eliminating any immediate payoff from thelytoky.

If thelytoky is to reach a high frequency in a honey bee population, multiple factors must fall into place concurrently: a thelytokous mode of worker reproduction, targeting of worker reproduction to queen cells, and the relaxation of worker policing. In a large, outbred population the suppression of worker reproduction by worker policing may significantly reduce variance in both the mode and target of worker's reproductive efforts. Thus, thelytoky is unlikely to emerge. However, in a small, isolated population, faced with additional pressures such as a high rate of queen loss (above), genetic drift and founder effects may have resulted in the necessary combination of factors falling into place for thelytoky to reach a stable point in the population.

\section{CONCLUSION}

The honey bee has played an important role in driving and informing evolutionary theory, a role that shows no sign of ending soon. Here, we have shown that the honey bee, and particularly the Capensis subspecies, has much to contribute to questions concerning the evolution of sex and asexuality. In Capensis, sex and asex co-exist, distributed among castes and lineages that share the same genetic background. Differing life histories results in divergent outcomes when the costs and benefits of sex and asexuality come into conflict. We suggest that the broader question of why sex evolved from ancestral asex, and how it has been maintained, should be addressed with an eye for more conditional costs and benefits.

We further propose that there may be broader implications to the insights provided by bees, ants and the haplodiploid Hymenoptera in general. In these species, a form of asexual reproduction, arrhenotoky, is ancestral. While arrhenotokous species still require sex for the production of females, this reproductive system is hypothesised to predispose haplodiploids to the evolution of true, 
thelytokous, asexuality (Engelstadter 2008; Rabeling and Kronauer 2013). In nonarrhenotokous species, the transition from sex back to asexuality is not as easy (Engelstadter 2008) and so the evolution of sex may be, in most circumstances, a one-way street. The question of "why is sex always better then asex?" then becomes "why is sex ever better then asex?" Sexual reproduction may evolve in a species during a period in which environmental conditions are such that the evolutionary tradeoff between sex and asex is similar to that faced by the Capensis queen, i.e. the need to invest maximally in a limited number of offspring. However, having taken this route, they cannot simply switch back to asex when conditions change. And so it is possible that there are many potential Clones waiting to emerge, but for these species asexuality is not a realistic evolutionary option, despite the benefits it may confer.

\section{Parthénogenèse thélytoque chez l'abeille}

Apis mellifera / Apis mellifera capensis / reproduction asexuée / thélytocie / parasitisme reproducteur

\section{Thelytökie bei Honigbienen}

Apis mellifera / Apis mellifera capensis / asexuale Reproduction / Thelytökie / reproduktiver Parasitismus

\section{REFERENCES}

Allsopp, M. (1992) The Capensis calamity. South African Bee Journal 64, 52-55

Allsopp, M., Crewe, R.M. (1993) The Cape honeybee as a Trojan horse rather than the hordes of Jenghiz Khan. Am. Bee. J. 133, 121-123

Allsopp, M., Calis, J.M., Boot, W. (2003) Differential feeding of worker larvae affects caste characters in the Cape honeybee, Apis mellifera capensis. Behav. Ecol. Sociobiol. 54, 555-561

Allsopp, M., Beekman, M., Gloag, R., Oldroyd, B.P. (2010) Maternity of replacement queens in the thelytokous Cape honey bee Apis mellifera capensis. Behav. Ecol. Sociobiol. 64, 567-574

Amdam, G.V., Seehuus, S.C. (2006) Order, disorder, death: lessons from a superorganism. Adv. Cancer Res. 95, 31-60
Amdam, G.V., Norberg, K., Fondrk, M.K., Page, R.E. (2004) Reproductive ground plan may mediate colony-level selection effects on individual foraging behavior in honey bees. Proc. Natl. Acad. Sci. USA 101, 11350-11355

Barron, A.B., Oldroyd, B.P., Ratnieks, F.L.W. (2001) Worker reproduction in honey-bees (Apis) and the anarchic syndrome: a review. Behav. Ecol. Sociobiol. 50, 199-208

Baudry, E., Kryger, P., Allsopp, M., Koeniger, N., Vautrin, D., et al. (2004) Whole-genome scan in thelytokous-laying workers of the Cape honeybee (Apis mellifera capensis): central fusion, reduced recombination rates and centromere mapping using half-tetrad analysis. Genetics 167, 243-252

Beekman, M., Oldroyd, B. (2008a) Who is the Queen's mother? Royal cheats in social insects. J. Biosci. 33, 159-161

Beekman, M., Oldroyd, B.P. (2008b) When workers disunite: intraspecific parasitism in eusocial bees. Annu. Rev. Entomol. 53, 19-37

Beekman, M., Calis, J.N.M., Boot, W.J. (2000) Parasitic honeybees get royal treatment. Nature 404, 723

Beekman, M., Good, G., Allsopp, M., Radloff, S., Pirk, C., et al. (2002) A non-policing honey bee colony (Apis mellifera capensis). Naturwissenschaften 89, 479-482

Beekman, M., Allsopp, M.H., Wossler, T.C., Oldroyd, B.P. (2008) Factors affecting the dynamics of the honeybee (Apis mellifera) hybrid zone of South Africa. Heredity 100, 13-18

Beekman, M., Allsopp, M.H., Jordan, L.A., Lim, J., Oldroyd, B.P. (2009) A quantitative study of worker reproduction in queenright colonies of the Cape honey bee, Apis mellifera capensis. Mol. Ecol. 18, 2722-2727

Beekman, M., Allsopp, M.H., Lim, J., Goudie, F., Oldroyd, B.P. (2011) Asexually produced Cape honeybee queens (Apis mellifera capensis) reproduce sexually. J. Hered. 102, 562-566

Beekman, M., Allsopp, M., Holmes, M., Lim, J., NoachPienaar, L.-A., et al. (2012) Racial mixing in South African honeybees: the effects of genotype mixing on reproductive traits of workers. Behav. Ecol. Sociobiol. 66, 897-904

Bessoltane, N., Toffano-Nioche, C., Solignac, M., Mougel, F. (2012) Fine scale analysis of crossover and non-crossover and detection of recombination sequence motifs in the honeybee (Apis mellifera). PLoS Biol. 7, e36229

Beye, M., Hasselmann, M., Fondrk, M.K., Page, R.E., Omholt, S.W. (2003) The gene $c d s$ is the primary signal for sexual development in the honeybee and encodes an SR-type protein. Cell 114, 419-429

Beye, M., Gattermeier, I., Hasselmann, M., Gemp, T., Schioett, M., et al. (2006) Exceptionally high levels of recombination across the honey bee genome. Genome Res. 16, 1339-1344

Blacher P., Yagound B., Lecoutey E., Devinne P., Chameron S., et al. (2013) Drifting behaviour as 
an alternative reproductive strategy for social insect workers. Proc. R. Soc. B. doi: http://dx.doi.org/ $10.1098 / \mathrm{rspb}$

Bull, J.J. (1994) Perspective-virulence. Evolution 48, 1423-1437

Calis, J.N.M., Boot, W.J., Allsopp, M.H., Beekman, M. (2002) Getting more than a fair share: nutrition of worker larvae related to social parasitism in the Cape honey bee Apis mellifera capensis. Apidologie 33, 193-202

Châline, N., Ratnieks, F.L.W., Burke, T. (2002) Anarchy in the UK: detailed genetic analysis of worker reproduction in a naturally occurring British anarchistic honeybee, Apis mellifera, colony using DNA microsatellites. Mol. Ecol. 11, 1795-1803

Chapman, N.C., Nanork, P., Gloag, R.S., Wattanachaiyingcharoen, W., Beekman, M., et al. (2009) Queenless colonies of the Asian red dwarf honey bee (Apis florea) are infiltrated by workers from other queenless colonies. Behav. Ecol. 20, $817-820$

Cobey, S. (1999) The African bee, Apis mellifera scutellata, threatened in her South African homeland by the Cape bee, Apis melliera capensis. Am. Bee. J. 139, 462-467

Daly, H.V. (1966) Biological studies on Ceratina dallatorreana, an alien bee in California which reproduces by parthenogenesis (Hymenoptera: Apoidea). Ann. Entomol. Sco. Am. 59, 1138-1154

Dietemann, V., Lubbe, A., Crewe, R.M. (2006a) Human factors facilitating the spread of a parasitic honey bee in South Africa. J. Econ. Entomol. 99, 7-13

Dietemann, V., Pflugfelder, J., Härtel, S., Neumann, P., Crewe, R. (2006b) Social parasitism by honeybee workers (Apis mellifera capensis Esch.): evidence for pheromonal resistance to host queen's signals. Behav. Ecol. Sociobiol. 60, 785-793

Engelstadter, J. (2008) Constraints on the evolution of asexual reproduction. BioEssays 30, 1138-1150

Engelstadter, J., Sandrock, C., Vorburger, C. (2010) Contagious parthenogenesis, automixis, and a sex determination meltdown. Evolution 65, 501-511

Fournier, D., Estoup, A., Orivel, R.M., Foucaud, J., Jourdan, H., et al. (2005) Clonal reproduction by males and female in the little fire ant. Nature $\mathbf{4 3 5}$, 1230-1234

Gladyshev, E., Meselson, M. (2008) Extreme resistance of bdelloid rotifers to ionizing radiation. Proc. Natl. Acad. Sci. USA 105, 5139-5144

Goudie, F., Allsopp, M.H., Beekman, M., Lim, J., Oldroyd, B.P. (2012a) Heritability of worker ovariole number in the Cape honey bee Apis mellifera capensis. Insectes Soc. 59, 351-359

Goudie, F., Allsopp, M.H., Beekman, M., Oxley, P.R., Lim, J., et al. (2012b) Maintenance and loss of heterozygosity in a thelytokous lineage of honey bees (Apis mellifera capensis). Evolution 66, 1897-1906
Goudie, F., Allsopp, M.H., Oldroyd, B.P. (2014) Selection on overdominant genes maintains heterozygosity along multiple chromosomes in a clonal lineage of honey bee. Evolution 68, 125136

Greeff, J.M. (1996) Effects of thelytokous worker reproduction on kin-selection and conflict in the Cape honeybee, Apis mellifera capensis. Philos. Trans.: Biol Sci. 351, 617-625

Greeff, J.M., Villet, M.H. (1993) Deducing the coefficient of relationship by the amount of recombination produced during automictic parthneogenesis. Heredity 70, 499-502

Gruber M., Hoffmann B., Ritchie P., Lester P.. (2010) Crazy ant sex: genetic caste determination, clonality, and inbreeding in a apopulation of invasive Yellow crazy ants. In: Nash D.R., den Boer S.P.A., Fine Licht H.H., and Boomsma J.J. (Eds.), XVI Congress of the International Union for the Study of Social Insects, Copenhagen, Denmark.

Hagimori, T., Abe, Y., Date, S., Miura, K. (2006) The first finding of a Rickettsia bacterium associated with parthenogenesis induction among insects. Curr. Microbiol. 52, 97-101

Hamilton, W.D. (1964) The genetical evolution of social behaviour. I \& II. J. Theor. Biol. 7, 1-52

Härtel, S., Neumann, P., Kryger, P., von der Heide, C., Moltzer, G., et al. (2006) Infestation levels of Apis mellifera scutellata swarms by socially parasitic Cape honeybee workers (Apis mellifera capensis). Apidologie 37, 462-470

Härtel, S., Wossler, T., Moltzer, G.-J., Crewe, R., Moritz, R.A., et al. (2011) Pheromone-mediated reproductive dominance hierarchies among pseudo-clonal honeybee workers (Apis mellifera capensis). Apidologie 42, 659-668

Hepburn, H.R., Allsopp, M.H. (1994) Reproductive conflict between honeybees: usurpation of Apis mellifera scutellata colonies by Apis mellifera capensis. Suid-Afrikaanse Tydskrif vir Wetenskap 90, 247-249

Hepburn, H.R., Crewe, R.M. (1990) Defining the Cape honeybee: reproductive traits of queenless workers. S. Afr. J. Sci. 86, 524-527

Hepburn, H.R., Crewe, R.M. (1991) Portrait of the Cape honeybee, Apis mellifera capensis. Apidologie 22, $567-580$

Hepburn, H.R., Radloff, S.E. (1998) Honeybees of Africa. Springer, Berlin

Heubel, K.U., Rankin, D.J., Kokko, H. (2009) How to go extinct by mating too much: population consequences of male mate choice and efficiency in a sexual-asexual species complex. Oikos 118, 513-520

Hillesheim, E., Koeniger, N., Moritz, R.F.A. (1989) Colony performance in honeybees (Apis mellifera capensis Esch.) depends on the proportion of subordinate and dominant workers. Behav Ecol Sociobiol 24, 291-296 
Hölldobler, B., Wilson, E.O. (2008) The superorganism: the beauty, elegance, and strangeness of insect societies. W. W Norton, New York

Holmes, M.J., Oldroyd, B.P., Allsopp, M.H., Lim, J., Wossler, T.C., et al. (2010) Maternity of emergency queens in the Cape honey bee, Apis mellifera capensis. Mol. Ecol. 19, 2792-2799

Holmes, M.J., Oldroyd, B.P., Duncan, M., Allsopp, M.H., Beekman, M. (2013) Cheaters sometimes prosper: targeted worker reproduction in honeybee (Apis mellifera) colonies during swarming. Mol. Ecol. 22, 4298-4306

Huigens, M.E., Stouthamer, R. (2003) Parthenogenesis associated with Wolbachia. In: Bourtzis, K., Miller, T.A. (eds.) Insect symbiosis, pp. 247-266. CRC Press, Boca Raton

Jarosch, A., Stolle, E., Crewe, R.M., Moritz, R.F.A. (2011) Alternative splicing of a single transcription factor drives selfish reproductive behavior in honeybee workers (Apis mellifera). Proc. Natl. Acad. Sci. USA 108, 15282-15287

Johnson, B.R., Linksvayer, T.A. (2010) Deconstructing the superorganism: social physiology, reproductive groundplans, and sociogenomics. Q. Rev. Biol. 85, 57-79

Jones, J., Myerscough, M., Graham, S., Oldroyd, B.P. (2004) Honey bee nest thermoregulation: diversity promotes stability. Science 305, 402-404

Jordan, L.A., Allsopp, M.H., Oldroyd, B.P., Wossler, T.C., Beekman, M. (2008) Cheating honeybee workers produce royal offspring. Proc. R. Soc. Lond. B. Biol. Sci. 275, 345-351

Keller, L. (2007) Uncovering the biodiversity of genetic and reproductive systems: time for a more open approach-American Society of Naturalists E.O. Wilson award winner address. Am. Nat. 169, 1-8

Kobayashi, K., Hasegawa, E., Ohkawara, K. (2008) Clonal reproduction by males of the ant Vollenhovia emeryi (Wheeler). Entomol. Sci. 11, 167-172

Koetz A. (2013) The Asian honey bee (Apis cerana) and its strains - with special focus on Apis cerana Java genotype. Literature review. Brisbane.

Kryger, K. (2001) The Capensis pseudo-clone, a social parasite of African honey bees. In: Menzel, R., Rademacher, E. (eds.) International Union for the Study of Social Insects, p. 208. IUSSI, Berlin

Lattorff, H.M.G., Kryger, P., Moritz, R.F.A. (2005) Queen developmental time and fitness consequences for queens of clonal social parasitic honeybees (A. m. capensis) and its host $A$. m. scutellata. Insectes Soc 52, 238-241

Levin, B.R. (1996) The evolution and maintenance of virulence in microparasites. Emerg. Infect. Dis. J 2, 93-102

Mackensen, O. (1943) The occurrence of parthenogenetic females in some strains of honey-bees. J. Econ. Entomol. 36, 465-467

Maynard Smith, J. (1978) The Evolution of Sex. Cambridge University Press
Mark Welch, J.L., Mark Welch, D.B., Meselson, M. (2004) Cytogenetic evidence for asexual evolution of bdelloid rotifers. Proc. Natl. Acad. Sci. USA 101, 1618-1621

Martin, S., Wossler, T., Kryger, P. (2002) Usurpation of African Apis mellifera scutellata colonies by parasitic Apis mellifera capensis workers. Apidologie 33, 215-232

Mattila, H.R., Seeley, T.D. (2007) Genetic diversity in honey bee colonies enhances productivity and fitness. Science 317, 362-364

Montague, C.E., Oldroyd, B.P. (1998) The evolution of worker sterility in honey bees: an investigation into a behavioral mutant causing failure of worker policing. Evolution 52, 1408-1415

Moritz, R. (2002) Population dynamics of the Cape bee phenomenon: the impact of parasitic laying worker clones in apiaries and natural populations. Apidologie 33, 233-244

Moritz, R.F.A., Fuchs, S. (1998) Organization of honeybee colonies: characteristics and consequences of a superorganism concept. Apidologie 29, 7-21

Moritz, R.F., Haberl, M. (1994) Lack of meiotic recombination in thelytokous parthenogenesis of laying workers of Apis mellifera capensis (the Cape honeybee). Heredity 73, 98-102

Moritz, R.F.A., Southwick, E.E. (1992) Bees as superorganisms. Springer, Berlin

Moritz, R.F.A., Kryger, P., Allsopp, M.H. (1996) Competition for royalty in bees. Nature 384, 31

Moritz, R.F.A., Kryger, P., Allsopp, M.H. (1999) Lake of worker policing in the Cape honeybee (Apis mellifera capensis). Behaviour 136, 1079-1092

Moritz, R.F.A., Pflugfelder, J., Crewe, R.M. (2003) Lethal fighting between honeybee queens and parasitic workers (Apis mellifera). Naturwissenschaften 90, 378-381

Moritz, R.F.A., Lattorff, H.M.G., Crewe, R.M. (2004) Honeybee workers (Apis mellifera capensis) compete for producing queen-like pheromone signals. Proc. R. Soc. Lond. B. Biol. Sci. 271(Supplement 3), S98$\mathrm{S} 100$

Moritz, R., Pirk, C.W.W., Hepburn, H.R., Neumann, P. (2008) Short-sighted evolution of virulence in parasitic honeybee workers (Apis mellifera capensis Esch.). Naturwissenschaften 95, 507-513

Moritz, R.F.A., Lattorff, H.M.G., Crous, K.L., Hepburn, H.R. (2011) Social parasitism of queens and workers in the Cape honeybee (Apis mellifera capensis). Behav. Ecol. Sociobiol. 65, 735-740

Nanork, P., Paar, J., Chapman, N.C., Wongsiri, S., Oldroyd, B.P. (2005) Asian honey bees parasitize the future dead. Nature 437, 829

Nanork, P., Chapman, N.C., Wongsiri, S., Lim, J., Gloag, R.S., et al. (2007) Social parasitism by workers in queenless and queenright Apis cerana colonies. Mol. Ecol. 16, 1107-1114 
Neumann, P., Hepburn, H.R. (2002) Behavioural basis for social parasitism of Cape honeybees (Apis mellifera capensis). Apidologie 33, 165-192

Neumann, P., Moritz, R.F.A. (2002) The Cape honeybee phenomenon: the sympatric evolution of a social parasite in real time? Behav. Ecol. Sociobiol. 52, 271-281

Neumann, P., Radloff, S.E., Moritz, R.F.A., Hepburn, H.R., Reece, S.L. (2001) Social parasitism by honeybee workers (Apis mellifera capensis Escholtz): host finding and resistance of hybrid host colonies. Behav. Ecol. 12, 419-428

Neumann, P., Härtel, S., Kryger, P., Crewe, R.M., Moritz, R.F.A. (2011) Reproductive division of labour and thelytoky result in sympatric barriers to gene flow in honeybees (Apis mellifera L.). J. Evol. Biol. 24, 286-294

Normark, B.B. (2003) The evolution of alternative genetic systems in insects. Annu. Rev. Entomol. 48, 397-423

Oldroyd, B.P. (2002) The Cape honeybee: an example of a social cancer. Trends Ecol. Evol. 17, 249-251

Oldroyd, B.P., Beekman, M. (2008) Effects of selection for honey bee worker reproduction on foraging traits. PLoS Biol. 6, e56

Oldroyd, B.P., Fewell, J.H. (2007) Genetic diversity promotes homeostasis in insect colonies. Trends Ecol. Evol. 22, 408-413

Oldroyd, B. P., Smolenski, A. J., Cornuet, J.-M., Crozier, R. H. (1994) Anarchy in the beehive. Nature 371, 749

Oldroyd, B.P., Allsopp, M.H., Gloag, R.S., Lim, J., Jordan, L.A., et al. (2008) Thelytokous parthenogenesis in unmated queen honeybees (Apis mellifera capensis): central fusion and high recombination rates. Genetics 180, 359-366

Oldroyd, B.P., Allsopp, M.H., Lim, J., Beekman, M. (2011) A thelytokous lineage of socially parasitic honey bees has retained heterozygosity despite at least 10 years of inbreeding. Evolution 65, 860-868

Onions, G.W. (1912) South African 'fertile worker bees'. Agr. J. U. S. Afr. 1, 720-728

Otto, S.P., Gerstein, A.C. (2006) Why have sex? The population genetics of sex and recombination. Biochem. Soc. Trans. 34(Part 4), 519-522

Page, R.E. (2013) The spirit of the hive. The mechanisms of social evolution. Harvard University Press, Cambridge, MA

Palmer, K.A., Oldroyd, B.P. (2000) Evolution of multiple mating in the genus Apis. Apidologie 31, 235-248

Pearcy, M., Aron, S., Doums, C., Keller, L. (2004) Conditional use of sex and parthenogenesis for worker and queen production in ants. Science 306, 1780-1783

Pearcy, M., Hardy, O., Aron, S. (2006) Thelytokous parthenogenesis and its consequences on inbreeding in an ant. Heredity 96, 377-382
Phiancharoen, M., Pirk, C.W.W., Radloff, S., Hepburn, R. (2010) Clinal nature of the frequencies of ovarioles and spermathecae in Cape worker honeybees, Apis mellifera capensis. Apidologie 41, 129134

Pirk, C.W.W., Neumann, P., Hepburn, H.R. (2002) Egg laying and egg removal by workers are positively correlated in queenright Cape honeybee colonies (Apis mellifera capensis). Apidologie 33, 203-211

Rabeling, C., Kronauer, D.J.C. (2013) Thelytokous parthenogenesis in eusocial hymenoptera. Annu. Rev. Entomol. 58, 273-292

Ratnieks, F.L.W. (1988) Reproductive harmony via mutual policing by workers in eusocial Hymenoptera. Am. Nat. 132, 217-236

Ratnieks, F.L.W., Visscher, P.K. (1989) Worker policing in honeybees. Nature 342, 796-797

Ravary, F., Jaisson, P. (2004) Absence of individual sterility in thelytokous colonies of the ant Cerapachys biroi Forel (Formicidae, Cerapachyinae). Insectes Soc. 51, 67-73

Ruttner, F. (1977) The problem of the cape bee (Apis mellifera capensis Escholtz): parthenogenesis-size of population-evolution. Apidologie 8, 281-294

Seeley, T.D. (1989) The honey bee colony as a superorganism. Am. Scientist 77, 546-553

Seeley, T.D. (2010) Honeybee democracy. Princeton University Press, Princeton, NJ

Seeley, T.D., Tarpy, D.R. (2007) Queen promiscuity lowers disease within honeybee colonies. Proc. R. Soc. B 274, 67-72

Siddle, H.V., Kaufman, J. (2013) A tale of two tumours: comparison of the immune escape strategies of contagious cancers. Mol. Immunol. 55, 190-193

Solignac, M., Vautrin, D., Baudry, E., Mougel, F., Loiseau, A., et al. (2004) A microsatellite-based linkage map of the honeybee, Apis mellifera L. Genetics 167, 253-262

Solignac, M., Mougel, F., Vautrin, D., Monnerot, M., Cornuet, J.-M. (2007) A third-generation microsatellite-based linkage map of the honey bee, Apis mellifera, and its comparison with the sequence-based physical map. Genome Biol. 8, R66

Sumner, S., Keller, L. (2008) Social evolution: reincarnation, free-riding and inexplicable modes of reproduction. Curr. Biol. 18, R206-R207

Suomalainen, E., Saura, A., Lokki, J. (1987) Cytology and evolution in parthenogenesis. CRC Press, Boca Raton, FL

Tiedemann, R., Moll, K., Paulus, K.B., Schlupp, I. (2005) New microsatellite loci confirm hybrid origin, parthenogenetic inheritance, and mitotic gene conversion in the gynogenetic Amazon molly (Poecilia formosa). Mol. Ecol. Notes 5, 586-589

Tribe, G.D. (1983) What is the Cape bee? South African Bee Journal 55, 77-87 
Verma, S., Ruttner, F. (1983) Cytological analysis of thelytokous parthenogenesis in the Cape honey bee Apis mellifera capensis. Apidologie 14, 4157

Visscher, P.K. (1989) A quantitative study of worker reproduction in honey bee colonies. Behav. Ecol. Sociobiol. 25, 247-254

Weinberg, R. (1998) One renegade cell: the quest for the origins of cancer. Phoenix, London

Wenseleers, T., Alves, D.A., Francoy, T.M., Billen, J., Imperatiz-Fonseca, V.L. (2011) Intraspecific queen parasitism in a highly eusocial bee. Biol. Lett. 7, 173-176

Wheeler, W.M. (1911) The ant-colony as an organism. Morphology 22, 307-325
White, M. (1984) Chromosomal mechanisms in animal reproduction. Bull. Zoo. 51, 1-23

Winston, M.L. (1991) The biology of the honey bee. Harvard University Press, Harvard

Wirtz, P., Beetsma, J. (1972) Induction of caste differentiation in the honey bee (Apis mellifera) by juvenile hormone. Entomol. Exp. Appl. 15, 517-520

Woyke, J. (1963) What happens to diploid drone larvae in a honeybee colony? J. Apic. Res. 2, 73-75

Zchori-Fein, E., Gottlieb, Y., Kelly, S.E., Brown, J.K., Wilson, J.M., et al. (2001) A newly discovered bacterium associated with parthenogenesis and a change in host selection behavior in parasitoid wasps. Proc. Natl. Acad. Sci. USA 98, 1255512560 